\title{
A COMPARATIVE PITTING CORROSION STUDY OF MILD STEEL IN DIFFERENT ALKALINE SOLUTIONS CONTAINING SALTS WITH SULPHUR-CONTAINING ANIONS
}

\author{
D. V. Vasquez Moll, R. C. Salvarezza, H. A. Videi a and A. J. Arvía \\ Instituto de Investigaciones Fisicoquímicas Teóricas y Aplicadas INIFTA, C.C. 16, Suc. 4. \\ 1900 La Plata, Argentina
}

\begin{abstract}
The localized corrosion of mild steel in alkaline solutions containing a salt with a sulphurcontaining anion (sodium sulphate, sodium sulphite, sodium thiosulphate, potassium thiocyanate and sodium sulphide) is studied by using potentiostatic and potentiodynamic techniques complemented with scanning electron microscopy. Alkaline solutions containing one of those salts produce pitting of mild steel at potential values more positive than those of the active-passive transition of iron in base. In the presence of either thiocyanate or thiosulphate anion iron pitting takes place through sulphide formation which reacts at the electrode surface yielding poorly protective ferrous sulphide. At potential more positive than the breakdown potential the kinetic behaviour fits a competitive surface reaction mechanism involving the formation of the passive film and the nucleation and growth of a ferrous sulphide salt layer. The proposed reaction model reproduces the corresponding experimental current-transients.
\end{abstract}

\section{INTRODUCTION}

IN THE last few years, the localized corrosion of iron and steel produced by sulphur compounds dissolved in corrosive solutions was carefully considered both from practical and fundamental standpoints. ${ }^{1-13}$ Both sulphide ${ }^{1.2}$ and sulphate ions ${ }^{3-5}$ in solution and elemental sulphur ${ }^{6}$ produce pitting corrosion in iron and mild steel. Sulphide ions promote corrosion of stainless steel by chloride ions. ${ }^{7,8}$ A similar effect is observed for stainless steel in a mixture of chloride and thiocyanate ions as well as chloride and thiosulphate ions. ${ }^{9}$ In both cases, at a constant chloride concentration, the increase of sulphur containing anion concentration shifts the corresponding breakdown potential towards more negative values. Intergranular corrosion and pitting of stainless steel in solutions containing only potassium thiocyanate is also reported. ${ }^{10}$

When pitting of both iron and stainless steel occurs in the presence of either sulphide, thiosulphate or other polythionic anion, sulphur and ferrous sulphide are formed inside the pits. ${ }^{2,9,11}$ Carbon steel in neutral phosphate buffer containing sodium thiosulphate exhibits a large increase in the anodic current related to the active-passive transition which is assigned to the formation of a thiosulphate-iron(II) complex. ${ }^{12}$ Similar electrochemical behaviour of carbon steel is found in alkaline ${ }^{2,13}$ and neutral phosphate-borate solution containing sodium sulphide. ${ }^{14}$

This paper refers to the pitting of mild steel in base solution with different sulphur-containing anions in order to determine whether these anions cause pitting

Manuscript received 18 November 1983 


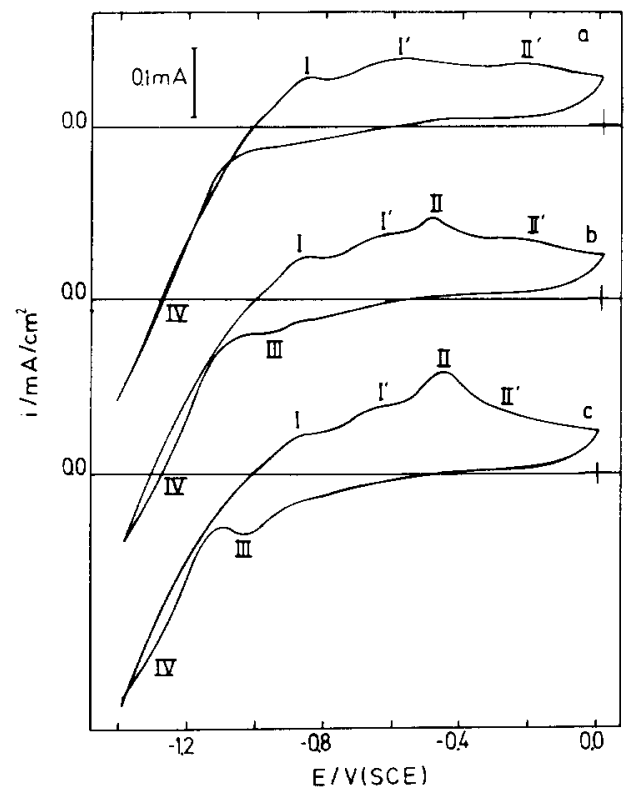

Fig. 1. E/i profiles at $0.02 \mathrm{~V} \mathrm{~s}^{-1}$ between -1.40 and $0.0 \mathrm{~V}$ (SCE) in $2 \times 10^{-3} \mathrm{M}$ sodium hydroxide. (a) first scan, (b) third scan, (c) fifth scan.

directly or through other ionic or molecular species resulting from their decomposition in solution. In this sense the electrochemical behaviours of mild steel in base solution with different sulphur-containing anions, are compared.

\section{EXPERIMENTAL METHOD}

Each working electrode consisted of a 1020 SAE steel rod (mild steel) axially embedded in an Araldite holder to offer an active flat disc shaped surface of $0.2 \mathrm{~cm}^{2}$ geometric area. The metal surface was firstly mechanically polished with fine grained emery paper followed by successive polishings with 1 and $0.3 \mu \mathrm{m}$ alumina paste. Then the polished metal surface was rinsed with acetone, alcohol and distilled water and finally dried in air at room temperature.

Electrolyte solutions, $2 \times 10^{-3} \mathrm{M} \mathrm{NaOH}+x \mathrm{M}$ of a sulphur-containing sodium or potassium salt $\left(\mathrm{Na}_{2} \mathrm{SO}_{4}, \mathrm{Na}_{2} \mathrm{~S}_{2} \mathrm{O}_{3}, \mathrm{Na}_{2} \mathrm{~S}, \mathrm{Na}_{2} \mathrm{SO}_{3}, \mathrm{KSCN} ; 10^{-5} \mathrm{M}<x<2 \times 10^{-3} \mathrm{M}\right.$ ) were prepared from twice distilled water and purged with purified nitrogen for $3 \mathrm{~h}$. Runs were made at $25 \pm 0.1^{\circ} \mathrm{C}$ using a single compartment electrochemical cell. The potential of the working electrode was measured against a saturated calomel electrode (SCE) (Radiometer K-701) connected to the rest of the cell through a Luggin-Haber capillary tip and shielded with a second salt bridge filled with saturated potassium nitrate to avoid chloride ion diffusion into the cell. The counter electrode was a platinum wire. Potential current density $(E / i)$ profiles resulting from single (STPS) or repetitive triangular potential scans (RTPS) and potentiostatic currenttransients $(i / t)$ were recorded. Prior to the experiments each electrode was held at $-1.40 \mathrm{~V}$ (SCE) for $90 \mathrm{~s}$ to electro-reduce any possible oxidized surface species. Several experiments were also made without precathodic treatment to eliminate the influence of possible electro-reduction products from sulphur-containing anions present in solution. The breakdown potential $\left(E_{\mathrm{b}}\right)$ was determined by the potentiostatic method, ${ }^{15}$ by using a new electrode each time. The latter was subjected to the following pretreatment: $90 \mathrm{~s}$ at $-1.40 \mathrm{~V}(\mathrm{SCE}), 90 \mathrm{~s}$ at $-0.74 \mathrm{~V}$ (SCE) and then the potential was held at the present value $\left(E_{\mathrm{s}}\right)$, the current being recorded during $5 \mathrm{~min}$. Finally, the electrode was removed from the solution and polished as described above and subjected to a stepwise $(0.02 \mathrm{~V})$ potential increase. This procedure was repeated until the potential corresponding to the sudden current increase was reached.

Microscopic observation of the electrode surface was made after removing the electrode from the 


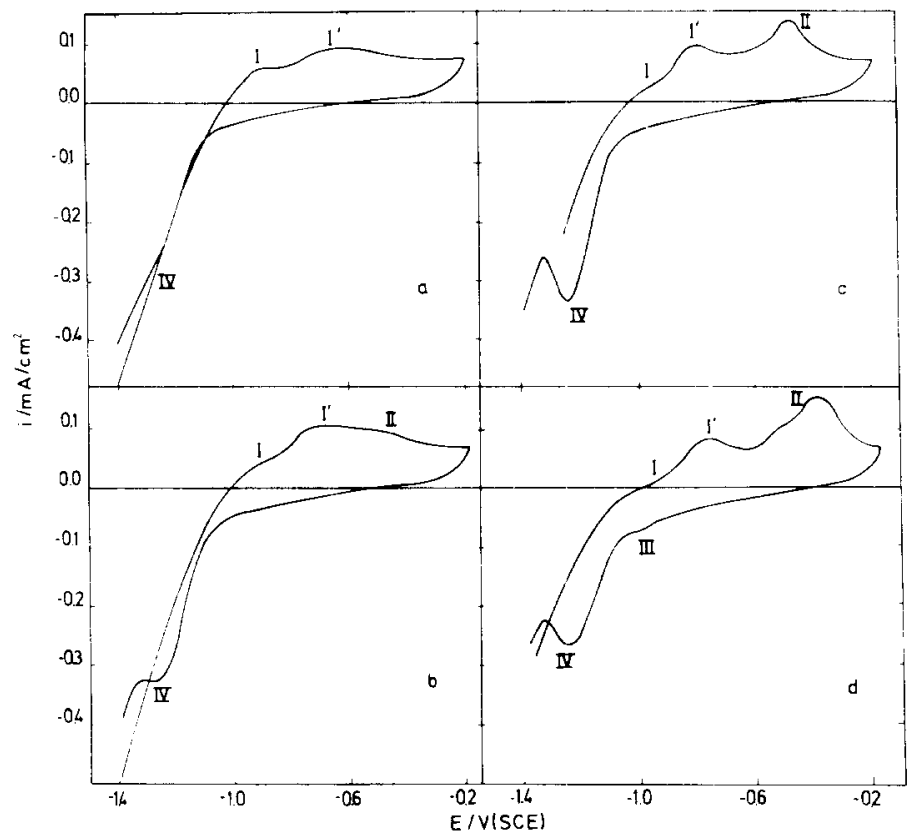

Fig. 2. STPS $E / i$ profiles at $0.02 \mathrm{~V} \mathrm{~s}^{-1}$ beteen -1.40 and $-0.20 \mathrm{~V}$ (SCE) in $2 \times 10^{-3} \mathrm{M}$ sodium hydroxide containing different sodium thiosulphate concentrations: (a) $1 \times 10^{-5} \mathrm{M}$.

(b) $1 \times 10^{-4} \mathrm{M}$, (c) $2.4 \times 10^{-4} \mathrm{M}$, (d) third scan in $1 \times 10^{-4} \mathrm{M}$.

electrolyte, washing with nitrogen-saturated twice distilled water and dried under nitrogen. SEM patterns were pictured from a Philips SEM 500 equipment.

\section{EXPERIMENTAL RESULTS}

\section{Voltammetric data}

$E / i$ displays recorded in $2 \times 10^{-3} \mathrm{M} \mathrm{NaOH}$ using a STPS at $0.02 \mathrm{~V} \mathrm{~s}^{-1}$ between $E_{\mathrm{s}, \mathrm{c}}=-1.40 \mathrm{~V}(\mathrm{SCE})$ and $E_{\mathrm{s}, \mathrm{a}}=0.00 \mathrm{~V}(\mathrm{SCE})$ show three broad and poorly defined current peaks at $-0.87 \mathrm{~V}$ (SCE) (peak I), $-0.60 \mathrm{~V}$ (SCE) (peak I') and $-0.20 \mathrm{~V}$ (SCE) (peak II') (Fig. 1a). The negative potential going scan shows a cathodic current contribution from $-0.55 \mathrm{~V}$ (SCE) downwards involving a hump at $-1.30 \mathrm{~V}$ (SCE) (hump IV). The $E / i$ displays resulting from RTPS show additional anodic and cathodic current peaks, the former located at $-0.50 \mathrm{~V}$ (SCE) (peak II) and the latter at $-0.95 \mathrm{~V}$ (SCE) (peak III) (Fig. 1b). During the RTPS, the heights of peaks II and III increase while those of I, I', II' and IV remain unchanged (Fig. 1c). In the first level (peaks $I$ and $I^{\prime}$ ), the iron electro-oxidation main product is assigned to $\mathrm{Fe}(\mathrm{OH})_{2},{ }^{16}$ which is further electro-oxidized to $\mathrm{FeOOH}$ in the second level (peaks II and $\left.\mathrm{II}^{\prime}\right) .{ }^{17}$ The iron oxy-hydroxide layer can also be transformed into a more stable film approaching the $\mathrm{Fe}_{3} \mathrm{O}_{4}$ /hydrated $\mathrm{Fe}_{2} \mathrm{O}_{3}$ structure. ${ }^{18}$ The electro-reduction of the iron oxy-hydroxide layer to $\mathrm{Fe}(\mathrm{OH})_{2}$ has been related to peak III while hump IV may involve the electro-reduction of some $\mathrm{Fe}(\mathrm{II})$ containing species. In the presence of $\mathrm{Na}_{2} \mathrm{~S}_{2} \mathrm{O}_{3}\left(<10^{-5} \mathrm{M}\right)$ the $E / i$ displays are qualitatively similar to those described for the plain base solution (Fig. 2a). The increase of $\mathrm{Na}_{2} \mathrm{~S}_{2} \mathrm{O}_{3}$ concentration results in the 


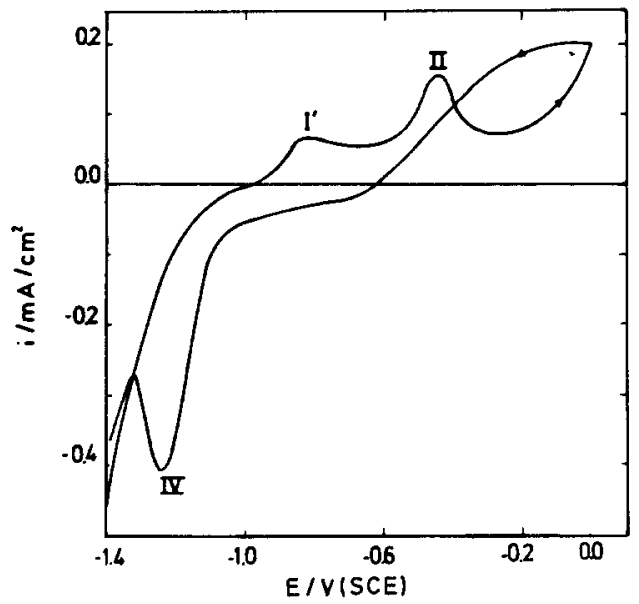

FIG. 3. STPS $E / i$ profile at $0.02 \mathrm{~V} \mathrm{~s}^{-1}$ between -1.40 and $0.00 \mathrm{~V}$ (SCE) in $2 \times 10^{-3} \mathrm{M}$ sodium hydroxide $+1.2 \times 10^{-3} \mathrm{M}$ sodium thiosulphate.

decrease of peak I and the increase of peak II (Figs. $2 b$ and c). In this case, hump IV becomes a well defined current peak. During the RTPS, the height of peak II increases and peak III becomes clearer (Fig. 2d). The E/i profile depends considerably on $E_{\mathrm{s}, \mathrm{a}}$ and particularly, when it exceeds $E_{\mathrm{b}}$, there is a net increase in the anodic current which is related to the localized corrosion of the mild steel. The threshold potential for the increase in the anodic current decreases as the $\mathrm{Na}_{2} \mathrm{~S}_{2} \mathrm{O}_{3}$ concentration increases. Thus, at $10^{-3} \mathrm{M}$, the anodic current increase is already observed at $-0.20 \mathrm{~V}$ (SCE) (Fig. 3). Likewise, the localized corrosion of mild steel shows isolated spots of a black corrosion product which are related to pitting corrosion. The EDAX analysis of these black spots reveals both sulphur and iron signals, indicating that the main corrosion product consists of iron sulphide.

To discard the electro-reduction of $\mathrm{Na}_{2} \mathrm{~S}_{2} \mathrm{O}_{3}$ to sulphide during the cathodization at $-1.40 \mathrm{~V}$ (SCE), STPS were made in $2 \times 10^{-3} \mathrm{M} \mathrm{NaOH}+1 \times 10^{-3} \mathrm{M} \mathrm{Na}_{2} \mathrm{~S}_{2} \mathrm{O}_{3}$ between the open circuit potential and $0.02 \mathrm{~V}$ (SCE). The open circuit potential approaches a quasi-stable value $(-0.70 \mathrm{~V}(\mathrm{SCE}))$ after $10 \mathrm{~min}$ of immersing the specimen in the solution. In this case, the activation of the metal occurs at greater potential values $[0.02 \mathrm{~V}(\mathrm{SCE})]$, probably because of the presence of a pre-existing oxide film on the electrode (Fig. 4). However, pitting and the simultaneous FeS spots are observed. This result is not surprising as $\mathrm{S}_{2} \mathrm{O}_{3}^{2-}$ ions undergo different disproportionation reactions yielding sulphite, sulphide and sulphate ions. ${ }^{19}$ To clarify the possible participation of $\mathrm{S}_{2} \mathrm{O}_{3}^{2-}$ ions in the pitting corrosion of mild steel, STPS $E / i$ profiles were recorded in $2 \times 10^{-3} \mathrm{M} \mathrm{NaOH}$ containing, in one case, $1.0 \times 10^{-3}$ $\mathrm{M} \mathrm{Na}_{2} \mathrm{SO}_{4}$ (Fig. 5) and another $1.2 \times 10^{-3} \mathrm{M} \mathrm{Na}_{2} \mathrm{~S}$ (Fig. 6). The addition of $\mathrm{SO}_{4}^{2-}$ ions produces no remarkable change in the STPS profile recorded between -1.40 and $0.00 \mathrm{~V}$ (SCE) (Fig. 5). However, when $E_{\mathrm{s}, \mathrm{a}}$ increases to $0.60 \mathrm{~V}$ (SCE), a considerable increase in the anodic current which is associated with pitting corrosion of mild steel is already seen when the applied potential is greater than $0.05 \mathrm{~V}$ (SCE) (Fig. 5). A similar behaviour is observed in $2 \times 10^{-3} \mathrm{M} \mathrm{NaOH}$ containing $1 \times 10^{-3} \mathrm{M} \mathrm{Na}_{2} \mathrm{SO}_{3}$. 


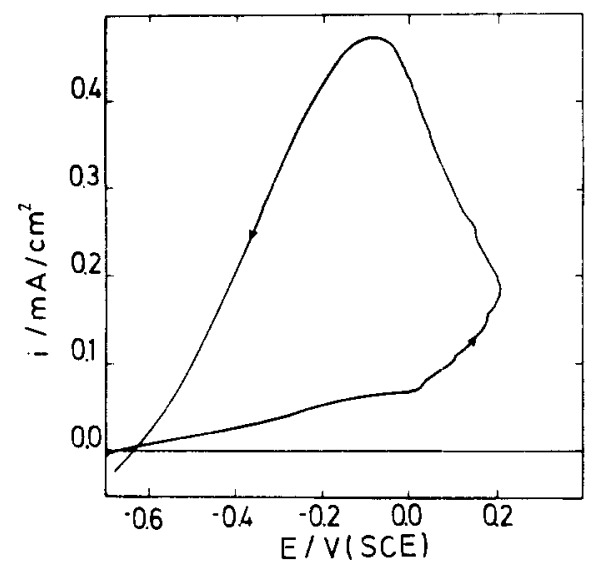

FIG. 4. STPS E/i profile at $0.02 \mathrm{~V} \mathrm{~s}^{-1}$ between -0.70 and $0.2 \mathrm{~V}(\mathrm{SCE})$ in $2 \times 10^{-3} \mathrm{M}$ sodium hydroxide $+1.0 \times 10^{-3} \mathrm{M}$ sodium thiosulphate.

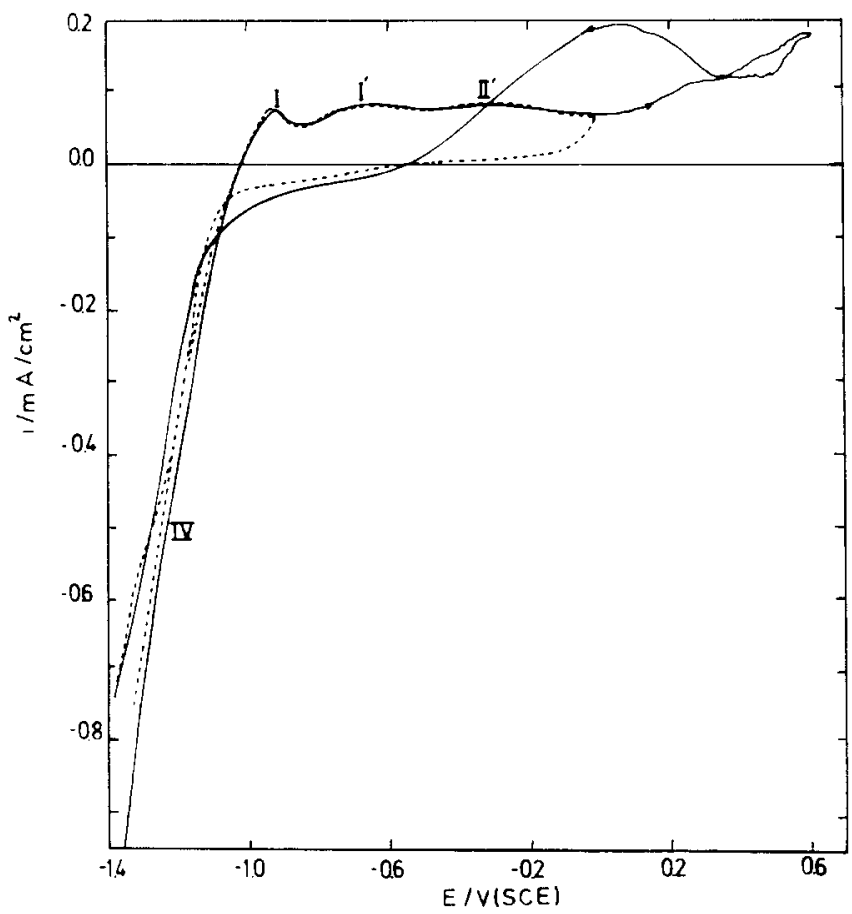

FIG. 5. STPS $E / i$ profiles at $0.02 \mathrm{~V} \mathrm{~s}^{-1}$ in $2 \times 10^{-3} \mathrm{M}$ sodium hydroxide $+1.0 \times 10^{-3} \mathrm{M}$ sodium sulphate between -1.40 and $0.0 \mathrm{~V}$ (SCE) $(---)$ and -1.40 and $0.6 \mathrm{~V}$ (SCE) (一). 


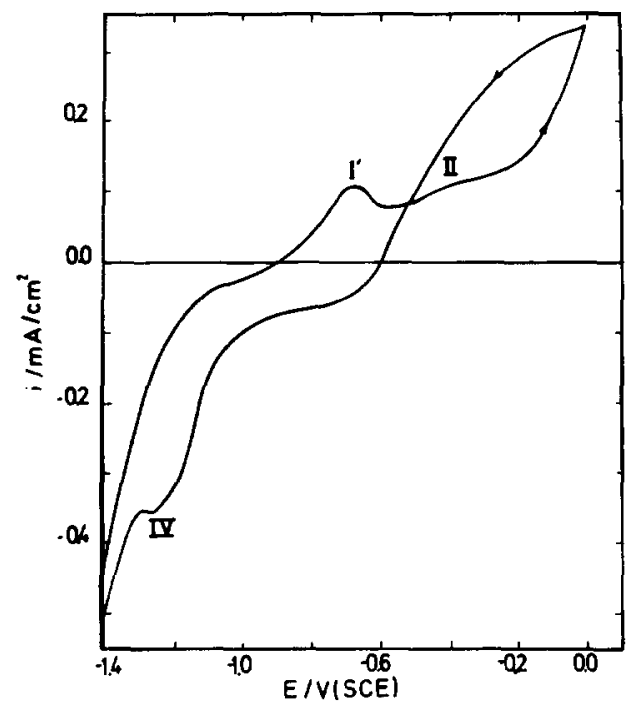

FIG. 6. STPS $E / i$ profile at $0.02 \mathrm{~V} \mathrm{~s}^{-1}$ between -1.40 and $0.0 \mathrm{~V}$ (SCE) in $2.0 \times 10^{-3} \mathrm{M}$ sodium hydroxide $+1.2 \times 10^{-3} \mathrm{M}$ sodium sulphide.

In $2 \times 10^{-3} \mathrm{M} \mathrm{NaOH}+1.2 \times 10^{-3} \mathrm{M} \mathrm{Na}_{2} \mathrm{~S}$, the $E / i$ profiles are similar to those in solutions containing $\mathrm{Na}_{2} \mathrm{~S}_{2} \mathrm{O}_{3}$ (Fig. 6). When the potential becomes more positive than $-0.20 \mathrm{~V}$ (SCE) pitting corrosion and FeS spots appear simultaneously.

Several experiments were also made in $2 \times 10^{-3} \mathrm{M} \mathrm{NaOH}$ containing $1 \times 10^{-3} \mathrm{M}$ KSCN. The corresponding E/i displays are similar to those described for $\mathrm{S}_{2} \mathrm{O}_{3}^{2-}$ and $\mathrm{S}^{2-}$ containing solutions. However, the activation of the metal corrosion occurs at a potential more positive than that observed in either thiosulphate or sulphide-containing solutions at the same concentration (Fig. 7).

\section{Breakdown potentials}

Breakdown potentials of mild steel in $2 \times 10^{-3} \mathrm{M} \mathrm{NaOH}$ with different sulphurcontaining anions as sodium or potassium salts $\left(1 \times 10^{-3} \mathrm{M}\right)$ are shown in Table 1 .

TABLE 1. BREAKDOWN POTENTIALS OF MILD STEEL IN

$2 \times 10^{-3} \mathrm{M}$ SODIUM HYDROXIDE CONTAINING VARIOUS SULPHUR ANIONS AT $25^{\circ} \mathrm{C}$

\begin{tabular}{lc}
\hline $\begin{array}{c}\text { Added electrolyte } \\
\left(10^{-3} \mathrm{M}\right)\end{array}$ & $\begin{array}{c}E_{\mathrm{b}} \\
{[\mathrm{V}(\mathrm{SCE})]}\end{array}$ \\
\hline Sodium sulphite & $-0.31 \pm 0.02$ \\
Sodium sulphate & $-0.44 \pm 0.02$ \\
Potassium thiocyanate & $-0.44 \pm 0.02$ \\
Sodium thiosulphate & $-0.52 \pm 0.02$ \\
Sodium sulphide & $-0.54 \pm 0.02$ \\
\hline
\end{tabular}




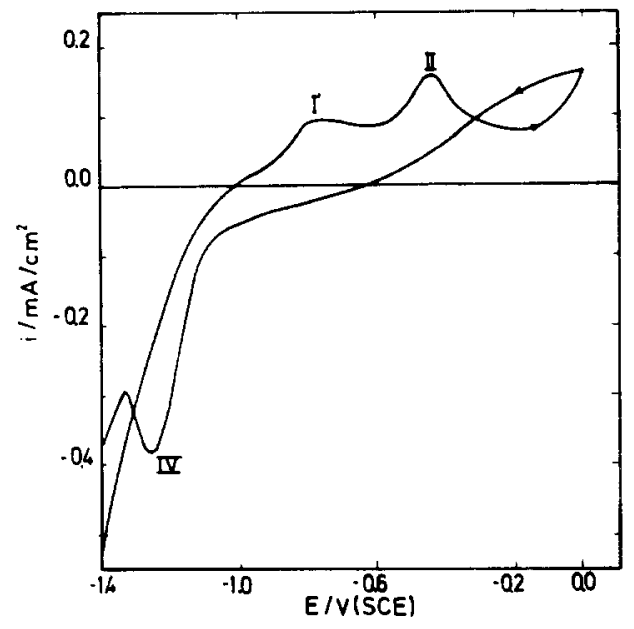

FIG. 7. STPS E/i profile at $0.02 \mathrm{~V}$ between -1.40 and $0.0 \mathrm{~V}$ (SCE) in $2.0 \times 10^{-3} \mathrm{M}$ sodium hydroxide $+1.0 \times 10^{-3} \mathrm{M}$ potassium thiocyanate.

For the same concentration, in the presence of $\mathrm{Na}_{2} \mathrm{~S}_{2} \mathrm{O}_{3}$ and $\mathrm{Na}_{2} \mathrm{~S} E_{\mathrm{b}}$ values are more negative than those obtained in either $\mathrm{Na}_{2} \mathrm{SO}_{4}, \mathrm{Na}_{2} \mathrm{SO}_{3}$ and $\mathrm{KSCN}$ containing solutions.

\section{Current transients}

Curent transients were recorded in $2 \times 10^{-3} \mathrm{M} \mathrm{NaOH}$ solution containing $1 \times$ $10^{-3} \mathrm{M} \mathrm{Na}_{2} \mathrm{~S}_{2} \mathrm{O}_{3}$. For this purpose, the electrode was precathodized at $E_{\mathrm{c}}=-1.40 \mathrm{~V}$ (SCE) during $t_{\mathrm{c}}=90 \mathrm{~s}$, later it was anodized at $E_{\mathrm{a}}=-0.74 \mathrm{~V}(\mathrm{SCE})$ during $t_{\mathrm{a}}=300 \mathrm{~s}$ and finally, stepped to the present potential, $E_{\mathrm{s}}\left[-0.60 \mathrm{~V}(\mathrm{SCE})<E_{\mathrm{s}}<-0.20 \mathrm{~V}\right.$ (SCE)] at which the current transient was recorded. Thus, when $E_{\mathrm{s}}<E_{\mathrm{b}}$ the current decreases continuously to attain the corresponding stationary value but when $E_{\mathrm{s}}>$ $E_{\mathrm{b}}$ (Fig. 8), the current transient exhibits firstly an induction time $\left(t_{\mathrm{i}}\right)$, then increases, reaches a maximum and finally attains a quasi-fluctuating relatively large value (Fig. 9). Macroscopic observations of the electrode surface during the rising transient reveals the appearance of black corrosion spots related to mild steel pitting. Initially, these spots grow radially at a fast rate and after a certain time the whole electrode surface becomes covered by the corrosion product. At a constant potential, the current associated with pit growth increases with time following the well known relationship

$$
I=I_{\mathrm{p}}+K\left(t-t_{\mathrm{i}}\right)^{b}
$$

where $I$ is the current measured on the whole electrode surface, $I_{\mathrm{p}}$ is the background current, $t_{\mathrm{i}}$ is the induction time, $K$ and $b$ are constants. The slope $(b)$ of the linear $\log \left(I-I_{\mathrm{p}}\right)$ vs $\log \left(t-t_{\mathrm{i}}\right)$ plot is between 1.25 and 1.30 (Fig. 10a). As the value of the potential step increases, $t_{1}$ decreases and in the $-0.48 \mathrm{~V}(\mathrm{SCE})<E_{\mathrm{s}}<-0.30$ $\mathrm{V}$ (SCE) range, the following relation is obeyed (Fig. 11).

$$
\log \left(t_{\mathrm{i}} / t_{\mathrm{o}}\right)=K^{\prime}\left(E_{\mathrm{s}}-E_{\mathrm{b}}\right)^{-1}=K^{\prime} \Delta E^{-1}
$$




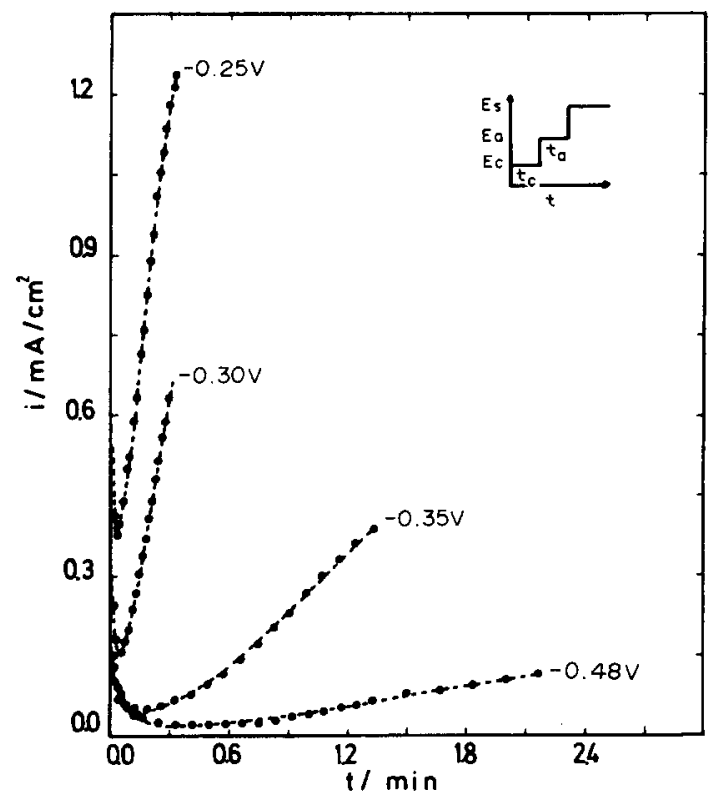

FIG. 8. Potentiostatic current transients $(\bullet)$ in $2 \times 10^{-3} \mathrm{M}$ sodium hydroxide $+1.0 \times 10^{-3}$ M sodium thiosulphate. $E_{\mathrm{c}}=-1.4 \mathrm{~V}(\mathrm{SCE}), t_{\mathrm{c}}=90 \mathrm{~s}, E_{\mathrm{a}}=-0.74 \mathrm{~V}(\mathrm{SCE}), t_{\mathrm{a}}=300 \mathrm{~s}, E_{\mathrm{b}}$ $=-0.52 \mathrm{~V}(\mathrm{SCE})$. Dashed traces correspond to current-transients calculated from equations (11), (12) and (14).

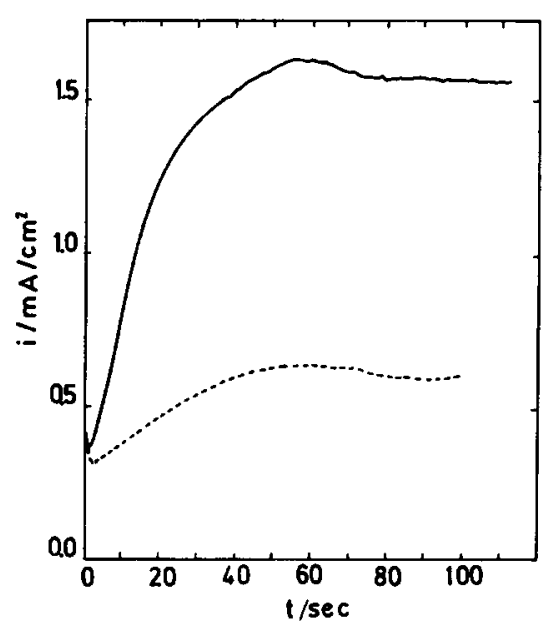

FIG. 9. Potentiostatic current transients at constant potential recorded in $2 \times 10^{-3} \mathrm{M}$ sodium hydroxide $+1.0 \times 10^{-3} \mathrm{M}$ sodium thiosulphate $(-)$ and $2 \times 10^{-3} \mathrm{M}$ sodium hydroxide $+1.0 \times 10^{-2} \mathrm{M}$ sodium sulphide (---). 


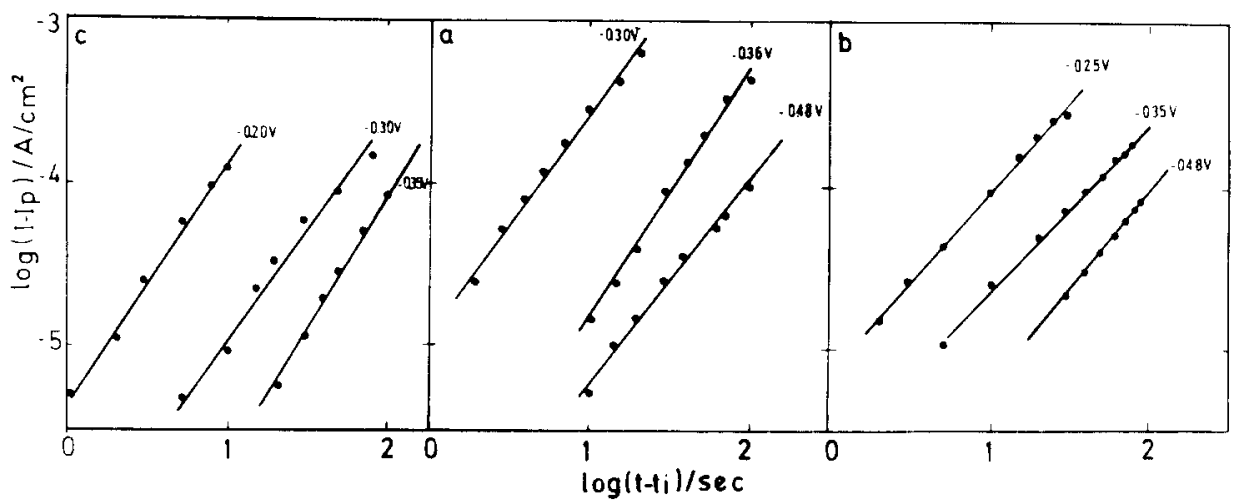

Fig. 10. $\log \left(I-I_{\mathrm{p}}\right)$ vs $\log \left(t-t_{\mathrm{i}}\right)$ plots: (a) $2 \times 10^{-3} \mathrm{M}$ sodium hydroxide $+1.0 \times 10^{-3.3} \mathrm{M}$ sodium thiosulphate, (b) $2 \times 10^{-3} \mathrm{M}$ sodium hydroxide $+1.0 \times 10^{-2} \mathrm{M}$ sodium sulphide, (c) $2 \times 10^{-3} \mathrm{M}$ sodium hydroxide $+1 \times 10^{-3} \mathrm{M}$ potassium thiocyanate.

where $K^{\prime}$ is a constant which depends on the electrolyte composition and $t_{0}=t_{\mathrm{i}}$ when $\Delta E \rightarrow \infty$. However, when $E_{\mathrm{s}}>-0.30 \mathrm{~V}(\mathrm{SCE}), t_{\mathrm{i}}$ becomes constant.

Current transients recorded in $2 \times 10^{-3} \mathrm{M} \mathrm{NaOH}+1 \times 10^{-3} \mathrm{M} \mathrm{Na}_{2} \mathrm{~S}$ and in $2 \times$ $10^{-3} \mathrm{M} \mathrm{NaOH}+1.0 \times 10^{-3} \mathrm{M} \mathrm{KSCN}$ are, in principle, similar to those already described for the $\mathrm{Na}_{2} \mathrm{~S}_{2} \mathrm{O}_{3}$ at the same $\mathrm{pH}$ and concentration (Figs. 12 and 13) as well as the corresponding $\log \left(I-I_{\mathrm{p}}\right)$ vs $\log \left(t-t_{\mathrm{i}}\right)$ and $\log t_{\mathrm{i}}$ vs $\Delta E^{-1}$ plots (Figs. $10 \mathrm{~b}, \mathrm{c}$ and 11). In $\mathrm{Na}_{2} \mathrm{~S}$ containing solutions the quasi-stable current is lower than that observed in $\mathrm{Na}_{2} \mathrm{~S}_{2} \mathrm{O}_{3}$ (Fig. 9).

After anodic polarization of the specimen for $2 \mathrm{~h}$ at $-0.20 \mathrm{~V}$ (SCE) in KSCN containing solutions a thick film of corrosion product is formed on the metal surface, the solution becomes slightly yellow tinged and a yellow-brown material appears at the cell bottom. The part of the film which contacts the metal is black and that of the

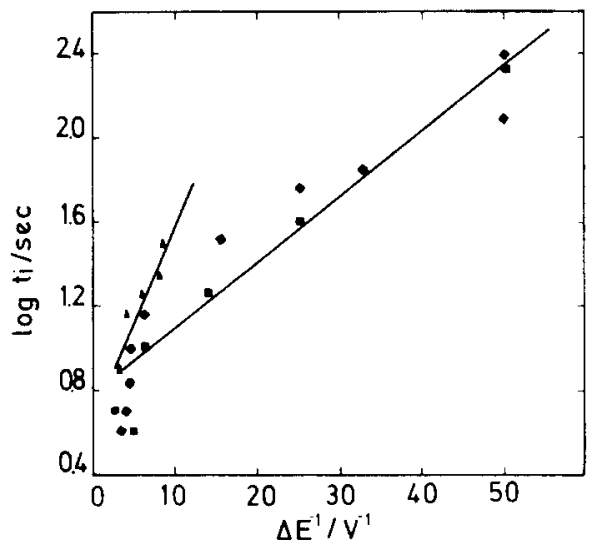

FIG. 11. Log $t_{\mathrm{i}}$ vs $\Delta E^{-1}$ plots. (•) $2 \times 10^{-3} \mathrm{M}$ sodium hydroxide $+1.0 \times 10^{-3} \mathrm{M}$ sodium thiosulphate. $(\Delta) 2 \times 10^{-3} \mathrm{M}$ sodium hydroxide $+1.0 \times 10^{-3} \mathrm{M}$ sodium sulphide, (A) $2 \times$ $10^{-3} \mathrm{M}$ sodium hydroxide $+1.0 \times 10^{-3} \mathrm{M}$ potassium thiocyanate 


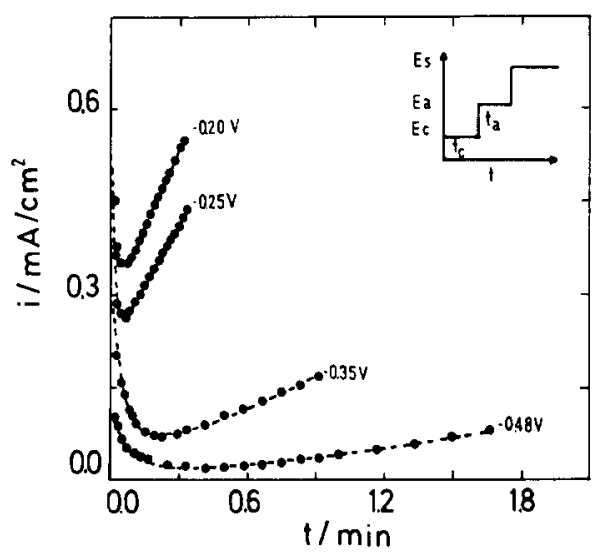

FIg. 12. Potentiostatic current transients ( $\bullet$ ) recorded in $2 \times 10^{-3} \mathrm{M}$ sodium hydroxide + $1.0 \times 10^{-3} \mathrm{M}$ sodium sulphide. $E_{\mathrm{c}}-1.40 \mathrm{~V}(\mathrm{SCE}), t_{\mathrm{c}}=90 \mathrm{~s}, E_{\mathrm{a}}=-0.74 \mathrm{~V}(\mathrm{SCE}), t_{\mathrm{a}}=300$ $\mathrm{s}, E_{\mathrm{b}}=-0.54 \mathrm{~V}(\mathrm{SCE})$. Dashed traces correspond to current-transients calculated from equations (11), (12) and (14).

solution side is brownish-black. In this case, $\mathrm{H}_{2} \mathrm{~S}$ is detected by dissolving the black material in dilute $\mathrm{H}_{2} \mathrm{SO}_{4}$, which suggests that $\mathrm{FeS}$ is formed during pitting. The material suspended in the solution after filtration and dissolution in diluted acid yields soluble ferric species indicating that $\mathrm{Fe}(\mathrm{III})$ species is also formed during pitting at this potential value. $\mathrm{Fe}(\mathrm{III})$ species is also detected after a $2 \mathrm{~h}$ polarizaton at $-0.20 \mathrm{~V}(\mathrm{SCE})$ in $\mathrm{Na}_{2} \mathrm{~S}_{2} \mathrm{O}_{3}$ containing solutions.

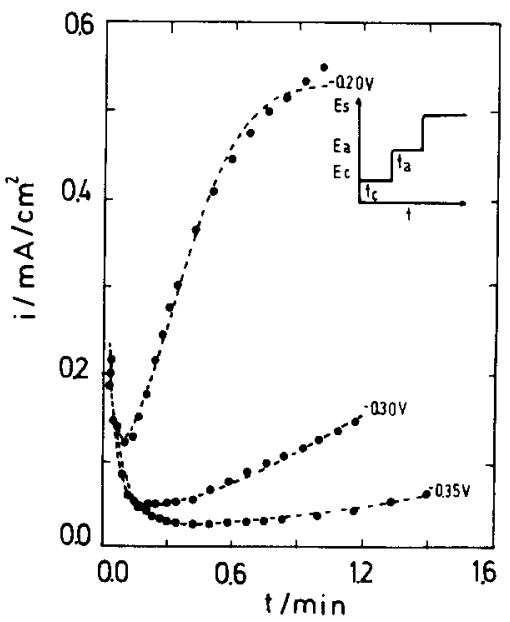

FIG. 13. Potentiostatic current transients ( $\bullet$ ) recorded in $2 \times 10^{-3} \mathrm{M}$ sodium hydroxide + $1.0 \times 10^{-3} \mathrm{M}$ potassium thiocyanate. $E_{\mathrm{c}}=-1.40 \mathrm{~V}(\mathrm{SCE}), t_{\mathrm{c}}=90 \mathrm{~s}, E_{\mathrm{a}}=-0.74 \mathrm{~V}(\mathrm{SCE})$, $t_{\mathrm{a}}=300 \mathrm{~s}, E_{\mathrm{b}}=-0.44 \mathrm{~V}(\mathrm{SCE})$. Dashed traces correspond to current-transients calculated from equations (11), (12) and (14). 

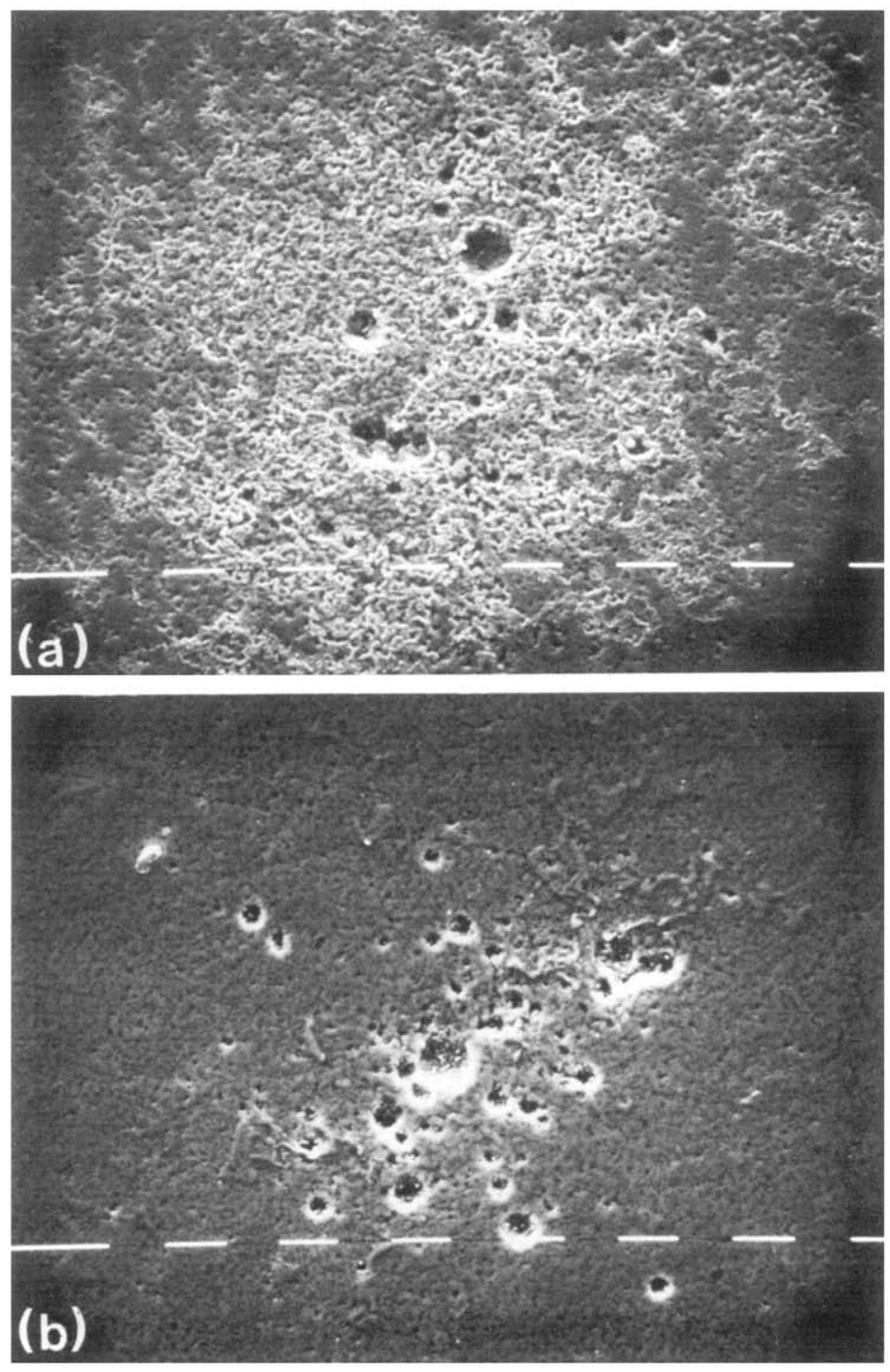

Fici, 14. (a) SEM pattern of mild steel surface after anodizing in $1.0 \times 10^{-3} \mathrm{M}$ sodium hydroxide $+1.0 \times 10^{-3}$ M sodium thiosulphate. $E_{\mathrm{c}}=-1.4\left(0 \mathrm{~V}(\mathrm{SCF}), t_{\mathrm{c}}=9() \mathrm{s}, E_{\mathrm{i}}=-0.74\right.$ $V(\mathrm{SCE}), t_{\mathrm{a}}=300 \mathrm{~s}, E_{\mathrm{s}}=-0.20 \mathrm{~V}(\mathrm{SCE}), t_{\mathrm{s}}=120 \mathrm{~s}$. Scale $10 \mu \mathrm{m}$. (b) SEM pattern of mild steel surface after anodizing in $2 \times 10^{3} \mathrm{M}$ sodium hydroxide $+1.0 \times 10^{-3} \mathrm{M}$ sodium sulphide. $E_{\mathrm{c}}=-1.40 \mathrm{~V}(\mathrm{SCF}), l_{\mathrm{c}}=9\left(0 \mathrm{~s}, E_{\mathrm{a}}=-0.74 \mathrm{~V}(\mathrm{SCE}), l_{\mathrm{a}}=300 \mathrm{~s}, E_{\mathrm{s}}=-0.20 \mathrm{~V}\right.$ (SCF), $T_{s}=120 \mathrm{~s}$. Scalc $10 \mu \mathrm{m}$. 

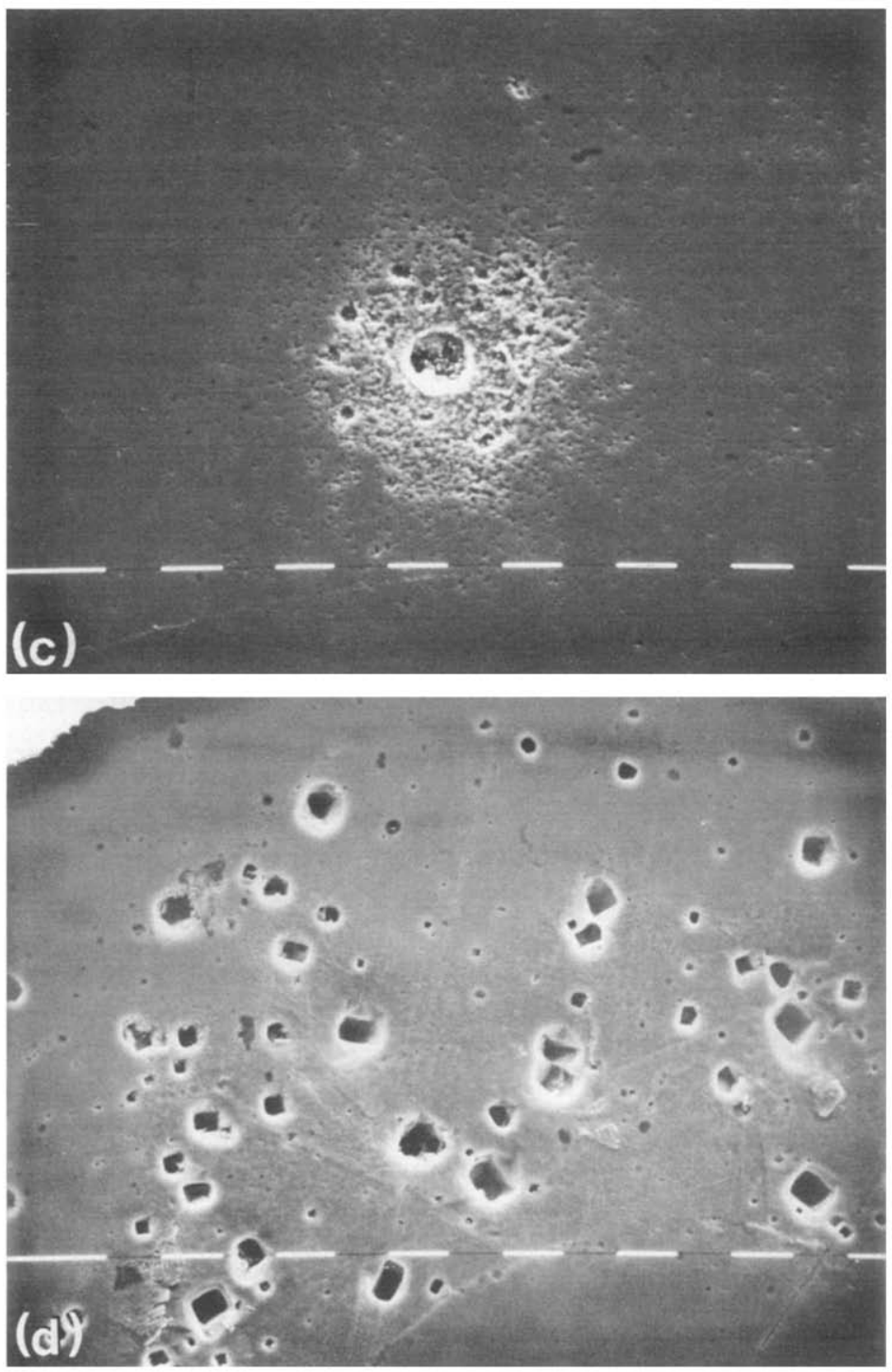

Fig. 14 (Cont.) (c) SEM pattern of mild steel surface after anodizing in $2 \times 10^{-3} \mathrm{M}$ sodium hydroxide $+1.0 \times 10^{-3} \mathrm{M}$ sodium thiosulphate. $E_{\mathrm{c}}=-1.40 \mathrm{~V}(\mathrm{SCE}), t_{\mathrm{c}}=90 \mathrm{~s}, E_{\mathrm{a}}=-0.74$ $\mathrm{V}(\mathrm{SCE}), t_{\mathrm{a}}=300 \mathrm{~s}, E_{\mathrm{s}}=-0.35 \mathrm{~V}(\mathrm{SCE}), t_{\mathrm{s}}=120 \mathrm{~s}$. Scale $10 \mu \mathrm{m}$. (d) SEM pattern of the metal surface after anodizing in $2 \times 10^{-3} \mathrm{M}$ sodium hydroxide $+1.0 \times 10^{-3} \mathrm{M}$ sodium sulphate. $E_{\mathrm{c}}=-1.40 \mathrm{~V}(\mathrm{SCE}), t_{\mathrm{c}}=90 \mathrm{~s}, E_{\mathrm{a}}=-0.74 \mathrm{~V}(\mathrm{SCE}), t_{\mathrm{a}}=300 \mathrm{~s}, E_{\mathrm{s}}=-0.20$ $\mathrm{V}(\mathrm{SCE}), t_{\mathrm{s}}=120 \mathrm{~s}$. Scale $10 \mu \mathrm{m}$. 


\section{Optical results}

Microscopic observations of mild steel specimens anodized at $-0.20 \mathrm{~V}$ (SCE) during $2 \mathrm{~min}$ in base solution ( $\mathrm{pH} 11.30$ ) in the presence of different sulphur-containing anions show qualitatively similar corrosion patterns as those resulting in $10^{-3} \mathrm{M}$ $\mathrm{Na}_{2} \mathrm{~S}_{2} \mathrm{O}_{3}$ and $10^{-3} \mathrm{M} \mathrm{Na}_{2} \mathrm{~S}$ containing solutions. In both cases hemispherical pits are produced on the mild steel surface (Figs. 14a and b). Each hemispherical pit is surrounded by a secondary etched area containing a large number of small crystallographic pits. The size of the secondary etched area decreases as the anodizing potential moves towards more negative values (Fig. 14c).

Hemispherical pits were also observed in the electrolyte containing potassium thiocyanate solutions. In this case, the secondary etched area at the same potential value is, however, smaller than that observed in the presence of thiosulphate and sulphide anions. Conversely, under comparable conditions, both in sodium sulphate and sodium sulphite, crystallographic pits are observed (Fig. 14d).

\section{DISCUSSION}

There is agreement that $\mathrm{S}$ and FeS are present within pits and cracks formed during stainless steel localized corrosion in chloride solutions containing thiosulphate anions. The localized corrosion is explained through a hindering of metal repassivation due to the local accumulation of sulphur and sulphides. ${ }^{9}$ Likewise, the role of polythionate ions in pitting corrosion can be explained in a similar way by taking into account that polythionates can be electro-reduced to thiosulphate on the steel surface. ${ }^{9.12}$ It is already known that during stress corrosion cracking, the solution in the growing crevice contacts steel which has been depleted in chromium and has lost its stainless behaviour. Results obtained with carbon steel show that $\mathrm{H}_{2} \mathrm{~S}$ promotes hydrogen permeation ${ }^{20}$ while thiosulphate ions promote anodic disolution without producing hydrogen permeation. ${ }^{12}$ Therefore, it was concluded that the corrosive effect of thiosulphate ions is due to the formation of a thiosulphate-iron (II) complex, so that the participation of sulphide species could be neglected. ${ }^{12}$

The present results show that thiosulphate anions are able to produce pitting of mild steel at a potential more positive than the potential of the active-passive transition and the main corrosion product related to pitting is FeS. It is already known that thiosulphate ions are metastable and undergo different reactions yielding sulphur species. For example, thiosulphate ions tend to decompose in alkaline solutions into sulphide and sulphate ions ${ }^{19}$ according to the following reaction:

$$
\mathrm{S}_{2} \mathrm{O}_{3}^{2-}+\mathrm{OH}^{-}=\mathrm{SH}^{-}+\mathrm{SO}_{4}^{2-} \text {. }
$$

This reaction is enhanced by the presence of cations which form insoluble sulphides. Otherwise, thiosulphate disproportionates in acid solutions as follows

$$
\begin{aligned}
2 \mathrm{H}^{+}+\mathrm{S}_{2} \mathrm{O}_{3}^{2-} & =\mathrm{S}^{\circ}+\mathrm{SO}_{3} \mathrm{H}_{2} \\
\mathrm{SO}_{3} \mathrm{H}_{2} & =\mathrm{SO}_{2}+\mathrm{H}_{2} \mathrm{O}
\end{aligned}
$$

The following reactions was also proposed to explain the FeS formation in the $\mathrm{Fe}(\mathrm{II}) / \mathrm{Fe}(\mathrm{Hg})$ system containing thiosulphate ions ${ }^{20}$ :

$$
\mathrm{Fe}+\mathrm{S}_{2} \mathrm{O}_{3}^{2-}=\mathrm{SO}_{3}^{2-}+\mathrm{FeS} \text {. }
$$


Besides, the electroreduction of thiosulphate ion to sulphur according to the reaction:

$$
\mathrm{S}_{2} \mathrm{O}_{3}^{2-}+6 \mathrm{H}^{+}+4 e=2 \mathrm{~S}+3 \mathrm{H}_{2} \mathrm{O}
$$

was also suggested. ${ }^{11}$ Recent studies on the mild steel corrosion in neutral water containing elemental sulphur show that sulphur is metastable and decomposes according to the following reaction ${ }^{22}$

$$
4 \mathrm{~S}+\mathrm{H}_{2} \mathrm{O}=3 \mathrm{SH}_{2}+\mathrm{SO}_{4} \mathrm{H}_{2} .
$$

Nevertheless, sulphate ions produce pitting of iron and carbon steel ${ }^{4,5,23}$ but $1 \times 10^{-3}$ $\mathrm{M} \mathrm{Na}_{2} \mathrm{SO}_{4}$ in $2 \times 10^{-3} \mathrm{M} \mathrm{NaOH}$ promote pitting at more positive potential values than $1 \times 10^{-3} \mathrm{M} \mathrm{Na}_{2} \mathrm{~S}_{2} \mathrm{O}_{3}$ and pit morphologies are quite different (Fig. $14 \mathrm{a}, \mathrm{b}$ and $\mathrm{d})$. Sulphite ions are also pitting producers on iron in acid media. ${ }^{24}$ However, the behaviour of sulphite ions is similar to that described for sulphate ions. On the other hand. E/i displays, breakdown potentials, induction times and corrosion patterns resulting in $\mathrm{Na}_{2} \mathrm{~S}$ and $\mathrm{Na}_{2} \mathrm{~S}_{2} \mathrm{O}_{3}$ are to some extent comparable. The presence of $\mathrm{FeS}$ within pits and the way of corrosion spread out on the metal indicates that sulphide ion is mainly responsible of mild steel pitting.

The appearance of FeS during mild steel pitting in thiocyanate solutions suggests that thiocyanate is also metastable. The following reaction has been proposed to explain the electrochemical behaviour of $\mathrm{Fe}(\mathrm{II}) / \mathrm{Fe}(\mathrm{Hg})$ system in thiocyanate solutions in the 3.85 to $9.70 \mathrm{pH}$ range. ${ }^{25}$

$$
\mathrm{Fe}+\mathrm{SCN}^{-}=\mathrm{SFe}+\mathrm{CN}^{-} \text {. }
$$

In thiocyanate-containing solutions $E_{\mathrm{b}}$ values are more positive and $t_{\mathrm{i}}$ values are larger than those corresponding to thiosulphate and sulphide containing solutions suggesting that mild steel pitting in the former case becomes more difficult than in the latter.

From the above discussion, it can be concluded that in base solution and the presence of either thiosulphate or thiocyanate ions pitting takes place through the formation of sulphide ions which react at the electrode surface yielding ferrous sulphide.

The electrochemical formation of FeS in base containing either $\mathrm{Na}_{2} \mathrm{~S}, \mathrm{Na}_{2} \mathrm{~S}_{2} \mathrm{O}_{3}$ or KSCN apparently fits a nucleation and growth mechanism involving FeS nuclei formation on the metal before pitting. This conclusion comes out from the fulfilment of equation (2) and from the current transients at $E_{\mathrm{a}}>E_{\mathrm{b}}$. Following the reaction model recently applied to pitting corrosion of mild steel in sodium fluoride solutions ${ }^{26}$ let us assume that the formation of salt nuclei competes with the formation of the passive layer at the iron surface so that the instantaneous anodic current $\left(i_{t}\right)$ can be considered as the sum of three main contributions:

$$
i_{\mathrm{t}}=i_{\mathrm{p}}+i_{\mathrm{c}}+i_{\mathrm{s}}
$$

where $i_{\mathrm{p}}, i_{\mathrm{c}}$ and $i_{\mathrm{s}}$ are the current for growing the passive film, the current of metal corrosion through the passive film and the current related to the salt growth, respectively.

The instantaneous passivity current $\left(i_{\mathrm{p}}\right)$ under potentiostatic conditions fits the 
equation predicted for an instantaneous nucleation and circular bidimensional growth under diffusion control, ${ }^{27}$ that is:

$$
i_{\mathrm{p}}=P_{1} \exp \left(-P_{2} t\right)
$$

where $P_{1}=q_{\text {mon }} \pi S^{2} D N_{0}$ and $P_{2}=\pi S^{2} D N_{0} . D\left(\mathrm{~cm}^{2} \mathrm{~s}^{-1}\right)$ denotes the diffusion coefficient of the reacting species coming from the solution. $q_{\text {mon }}\left(\mathrm{mC} \mathrm{cm}^{-2}\right)$ is the charge density required for the full coverage of the metal surface by the passivating species, $S$ is a proportionality constant, $N_{0}\left(\mathrm{~cm}^{-2}\right)$ corresponds to the number of sites per unit area available for nucleation at the metal surface.

On the other hand, the instantaneous current related to the salt layer growth apparently fits the kinetic expression for the instantaneous nucleation and tridimensional conical growth under charge transfer control. ${ }^{28}$ The corresponding expression is:

$$
i_{\mathrm{s}}=P_{4}\left[1-\exp \left(-P_{5} t^{2}\right)\right]
$$

where $P_{4}=z F k_{3 \mathrm{c}}^{\prime} ; P_{5}=\pi M^{2} k_{3 \mathrm{c}}^{2} N_{0} / \delta^{2} ; k_{3 \mathrm{c}}^{\prime}$ and $k_{3 \mathrm{c}}$ are the formal rate constants for the layer growth in the direction perpendicular and parallel to that of the metal plane. repectively; $\delta$ is the density of the salt whose molecular weight is $M$. When $t \rightarrow \infty$ equation (13) results:

$$
i_{\mathrm{s}}=P_{4} \text {. }
$$

Finally, the rate of metal dissolution through the passive layer appears as a time independent contribution, namely:

$$
i_{\mathrm{c}}=P_{3} \text {. }
$$

On the basis of equations (11), (12) and (14), the current transients shown in Figs. 8 , 12 and 13 can be reproduced over the whole time range covered in the present work, within a maximum error of $5 \%$, by using the parameters assembled in Table 2 .

In thiosulphate solutions as $E_{\mathrm{s}}$ increases $P_{1}, P_{2}, P_{3}, P_{4}$ and $P_{5}$ increase while in sulphide and thiocyanate solutions a similar behaviour of $P_{1}, P_{2}, P_{3}$ and $P_{5}$ is

Table 2. Parameters used to Reproduce the experimental CURrent transients (Figs. 8, 12 and 13)

\begin{tabular}{lcccccc}
\hline \multicolumn{1}{c}{ Anions } & $E_{\mathrm{s}}(\mathrm{V})$ & $\begin{array}{c}P_{1} \\
\left(\mathrm{~mA} \mathrm{~cm}^{-2}\right)\end{array}$ & $\begin{array}{c}P_{2} \\
\left(\mathrm{~min}^{-1}\right)\end{array}$ & $\begin{array}{c}P_{3} \\
\left(\mathrm{~mA} \mathrm{~cm}^{-2}\right)\end{array}$ & $\begin{array}{c}P_{4} \\
\left(\mathrm{~mA} \mathrm{~cm}^{-2}\right)\end{array}$ & $\begin{array}{c}P_{5} \\
\left(\mathrm{~min}^{-2}\right)\end{array}$ \\
\hline Thiosulphate & $-0.48 \mathrm{~V}$ & 0.136 & 13.03 & 0.0123 & 0.160 & 0.212 \\
{$\left[E_{\mathrm{b}}=-0.52 \mathrm{~V}(\mathrm{SCE})\right]$} & $-0.35 \mathrm{~V}$ & 0.190 & 30.14 & 0.0321 & 0.649 & 0.441 \\
& $-0.30 \mathrm{~V}$ & 0.337 & 57.47 & 0.1143 & 0.785 & 11.68 \\
& $-0.25 \mathrm{~V}$ & 1.368 & 201.34 & 0.359 & 1.003 & 18.72 \\
Sulphide & $-0.48 \mathrm{~V}$ & 0.101 & 12.25 & 0.0152 & 0.281 & 0.0889 \\
{$\left[E_{\mathrm{b}}=-0.54 \mathrm{~V}(\mathrm{SCE})\right]$} & $-0.35 \mathrm{~V}$ & 0.261 & 19.290 & 0.0621 & 0.296 & 0.533 \\
& $-0.25 \mathrm{~V}$ & 0.406 & 80.830 & 0.254 & 0.254 & 10.88 \\
& $-0.20 \mathrm{~V}$ & 0.389 & 68.33 & 0.327 & 0.283 & 12.99 \\
Thiocyanate & $-0.35 \mathrm{~V}$ & 0.275 & 14.16 & 0.0250 & 0.296 & 0.0619 \\
{$\left[E_{\mathrm{b}}=-0.44 \mathrm{~V}(\mathrm{SCE})\right]$} & $-0.30 \mathrm{~V}$ & 0.325 & 23.24 & 0.0409 & 0.296 & 0.337 \\
& $-0.20 \mathrm{~V}$ & 0.458 & 41.34 & 0.0968 & 0.434 & 5.321 \\
\hline
\end{tabular}


observed, but $P_{4}$ remains practically constant. However, for the three anions, the potential dependence of $P_{3}$ and $P_{5}$ expressed as $\Delta \log P / \Delta E$ is greater than that of $P_{4}$. This means that as the potential is set more positive, the parallel salt layer growth and the corrosion of the base metal is enhanced, both contributions assisting the fast radial growth of pits. This explains the corrosion patterns observed in the presence of the sulphur containing anions at high $E_{\mathrm{s}}$ values (Figs. 14a and b). The presence of a certain amount of Fe(III) is related to the large values of $P_{3}$ when the applied potential is close $-0.20 \mathrm{~V}(\mathrm{SCE})$. More defined pits are formed at more negative $E_{\mathrm{s}}$ values (Fig. 14c). In this case, the rate of change of the perpendicular salt growth with potential is smaller than that corresponding to the rate of change of parallel growth.

When the current transients reach the maximum, in the presence of the sulphur anions, the pitting area was close to $1 \%$ of the electrode surface. Then, the current associated with the perpendicular salt growth $\left(P_{4}\right)$ should be comprised between 16 and $100 \mathrm{~mA} \mathrm{~cm}^{-2}$. Finally, when $P_{4}$ values are compared at the same polarization measured with respect to $E_{\mathrm{b}}$, larger values are observed in thiosulphate and thiocyanate anion containing solutions than those corresponding to solutions containing sulphide. This is probably related to a ferrous suphide thin layer which is present inside the pits due to the formation of soluble iron(II) complexes in the presence of thiosulphate, ${ }^{12}$ thiocyanate or cyanide ${ }^{25}$ as already reported for iron pitting in the presence of complexing substances. ${ }^{29}$

Acknowledgements-INIFTA is sponsored by the Consejo Nacional de Investigaciones Científicas y Técnicas, the Universidad Nacional de La Plata and the Comisión de Investigaciones Científicas (Provincia de Buenous Aires). D. V. Vasquez Moll acknowledges the fellowship granted by the Deutscher Akademischer Austauschdienst, through the University of Mainz-University of La Plata Cooperation Agreement.

The authors thank Lic. C. A. Acosta for carrying out the experimental work.

\section{REFERENCES}

1. D. W. Shoesmith, M. G. Baley and B. IKedA, Electrochim. Acta 23, 1329 (1978).

2. R. C. Salvarezza, H. A. Videla and A. J. Arvía, Corros. Sci. 22, 815 (1982).

3. T. Kodama, Proc. Fifth Int. Congr. Metallic. Corros. p. 223. NACE, Houston (1975).

4. K. Ogura and T. Ohama, Corrosion 37, 569 (1981).

5. C. A. Acosta, R. C. Salvarezza, H. A. Videla and A. J. Arvía, Corros. Sci. (submitted).

6. S. B. Maldonado and P. J. Boden, Proc. VIII International Congress on Metallic Corrosion. Mainz (1982).

7. G. C. Pini and R. Calvillo, Werkstoffe Korros. 29, 303 (1978),

8. N. De Cristófaro, C. A. Acosta, R. C. Salvarezza and H. A. Videla, Memorias de la Vi Reunión Latinoamericana de Electroquímica y Corrosión. Oaxtepec, Mexico (1983).

9. R. C. Newman, H. S. Isaacs and B. Alman, Corrosion 38, 261 (1982).

10. A. B. IJzermans, Corros. Sci. 10, 607 (1970).

11. R. C. Newman, H. S. IsaAcs and K. Sieradzki, Metall. trans. (submitted 1981).

12. H. H. Horowitz, Corros. Sci. 23, 353 (1983).

13. D. Tromans, J. electrochem. Soc. 127, 1253 (1980)

14. R. C. Salvarezza, H. A. Videla and A. J. Arvía, Corros. Sci. 23, 717 (1983).

15. M. JANIK CZACHOR, Werkstoffe Korros. 31, 606 (1980).

16. R. S. Schrebler Guzmán, J. R. Vilche and A. J. Arvía, Electrochim. Acta 24, 395 (1979).

17. L. OJefors, J. electrochem. Soc. 123, 1694 (1976).

18. J. O. Zerbino, J. R. Vilche and A. J. Arvía, J. appl. Electrochem. 11, 703 (1981).

19. F. Burriel, F. Lucena and S. Arribas, Química Analítica Cualitativa (ed. Paraninfo). Madrid, España (1970).

20. B. J. Berkowitz and H. H. Hokowitz, J. electrochem. Soc. 129, 468 (1982). 
21. E. ItABashi, J. electroanal. Chem. 103, 189 (1979).

22. S. B. Maldonado and P. J. Boden, Br. Corros. J. 17, 116 (1982).

23. A. D. Keitelman and J. R. Galvele, Corros. Sci. 22, 739 (1982).

24. Ph. Berge, V. Jovancicevit, D. Nö̈l and P. Saint Paul, Extended Abstracts of the Electrochemical Society Meeting (169th meeting), Spring Meeting, Montreal. Canada (1982).

25. E. ItABashi, J. electroanal. Chem. 117, 295 (1981).

26. D. V. Vasquez Moll, C. A. Acosta, R. C. Salvarezza, H. A. Vidfi.a and A. J. Arvía, Corros. Sci. (submitted).

27. W. Davison and J. A. Harrison, J. electroanal. chem. 44, 213 (1973).

28. M. Y. Abyaneh and M. Fleischmann, Electrochim. Acta 27, 1518(1982).

29. K. Ogura and T. Ohama. Corrosion 38, 403 (1982). 